\title{
Intravitreal bevacizumab in choroidal neovascularization secondary to Grönblad-Strandberg' syndrome: case report
}

\author{
Uso de bevacizumab intravítreo em neovascularização coroidiana secundária \\ a síndrome de Grönblad-Strandberg: relato de caso
}

Ricardo Miguel Japiassú ${ }^{1}$

Maria Augusta Castro Farias Japiassú ${ }^{2}$

Mariana Gomes Pecego ${ }^{3}$

\begin{tabular}{|c|}
\hline ABSTRACT \\
\hline $\begin{array}{l}\text { Angioid streaks are commonly related to Grönblad-Strandberg syndrome, } \\
\text { that often shows dermatological characteristics, such as pseudoxanthoma } \\
\text { elasticum. Choroidal neovascularization is uncommon, often occurring } \\
\text { after ocular trauma. This is a case report of the successful use of intravitreal } \\
\text { bevacizumab for the treatment of choroidal neovascularization secondary } \\
\text { to Grönblad-Strandberg syndrome. }\end{array}$ \\
\hline
\end{tabular}

Keywords: Pseudoxanthoma elasticum; Angioid streaks; Choroidal neovascularization/ drug therapy; Angiogenesis inhibitors/therapeutic use; Case reports [Publication type]

\section{INTRODUCTION}

Grönblad-Strandberg syndrome is characterized by the development of yellowish confluent papules in the skin resembling peau d'orange, mainly on skinfolds, known as pseudoxanthoma elasticum. Angioid streaks are commonly related to this disease whereas choroidal neovascularization is uncommon $^{(1-2)}$, often occurring after ocular trauma.

Bevacizumab (Avastin ${ }^{\circledR}$, Genentech) is an agent that inhibits the effects of vascular endothelial growth factor (VEGF). Originally approved by the US Food and Drug Administration (FDA) for the treatment of colon cancer, bevacizumab has been used in an off-label manner to treat a variety of ocular diseases including choroidal neovascularization (CNV) secondary to age-related macular degeneration. More recently, bevacizumab has been offered as an alternative treatment option for patients with retinal vein occlusion and other causes, such as angioid streaks ${ }^{(1-5)}$.

This is a case report of the successful use of intravitreal bevacizumab for the treatment of choroidal neovascularization.

\section{CASE REPORT}

A 32-year-old male with a previous diagnosis of pseudoxanthoma elasticum, presented with complaints of decreased visual acuity in his right eye for two weeks. His left eye was seriously compromised after an ocular trauma, years ago. Visual acuity was 0.2 in OD and "hand movements" in OS. Biomicroscopy and tonometry were unremarkable. Fundus examination revealed bilateral angioid streaks, a disciform scar in OS, and in OD subretinal neovascularization and choroidal rupture, accompanied by a wide submacular hemorrhage, as seen on fluorescein angiography (Figure 1). 


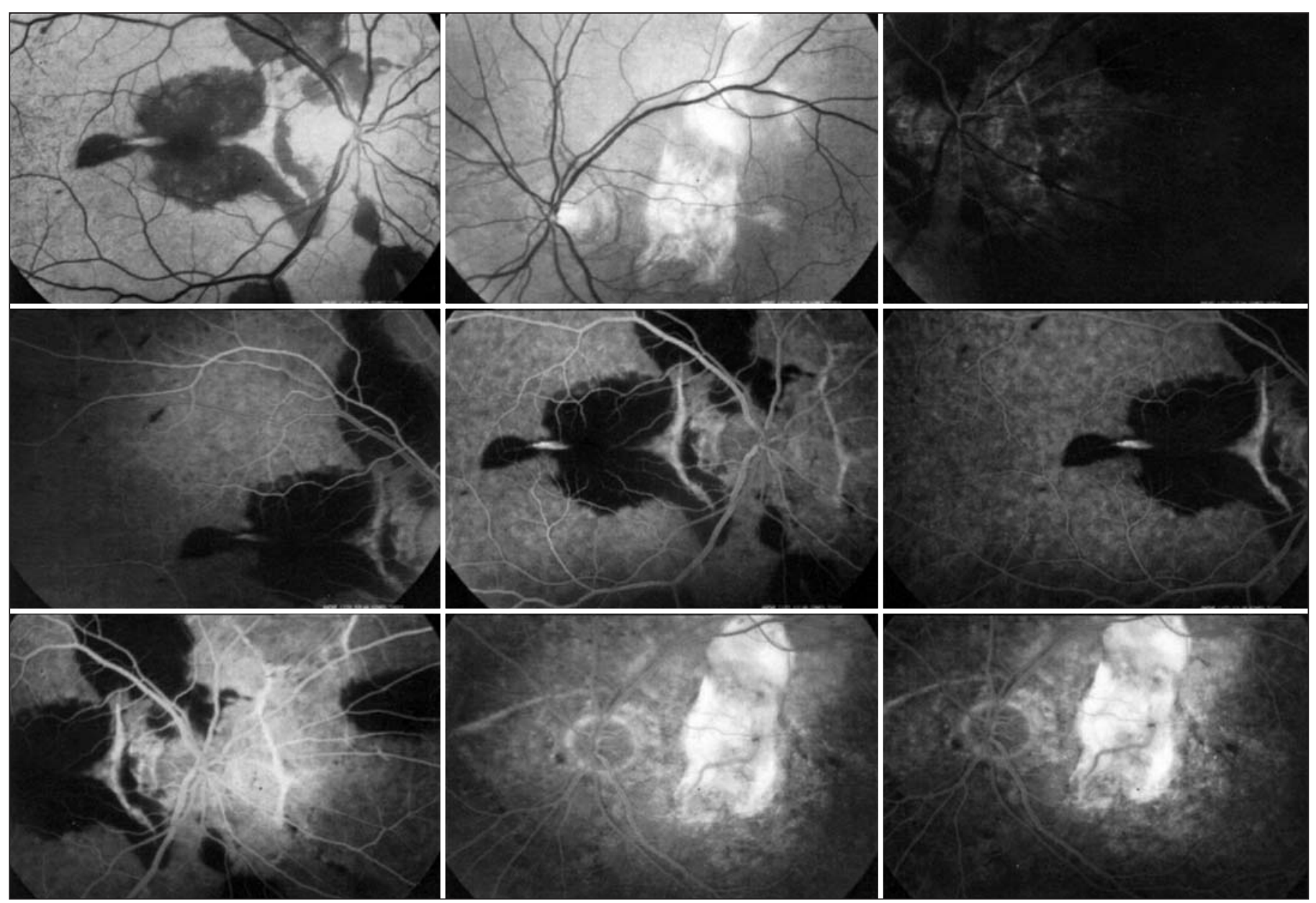

Figure 1 - A disciform scar in OS, and in OD subretinal neovascularization and choroidal rupture, accompanied by a wide submacular hemorrhage, as seen on fluorescein angiography

The option was for intravitreal bevacizumab (Avastin ${ }^{\circledR} / \mathrm{Ge}$ nentech, $1.25 \mathrm{mg}$ ) in OD due to known poor response of this disease to laser photocoagulation and photodynamic therapy. After one month, the patient's visual acuity was 0.7 in OD and there was no evidence of macular hemorrhage nor leaking of the neovascular complex (Figure 2). After four months, there still was no evidence of neovascular complex leakage nor hemorrhage, and best corrected visual acuity still was 0.7 .

\section{DISCUSSION}

Laser and photodynamic treatment for patients with choroidal neovascularization secondary to angioid streaks had statistically significant benefits in terms of retinal thickening and regression of the neovascular complex. There are crucial shortcomings with these treatment options, however. With laser treatment, visual acuity gains were marginal and other sessions of laser treatment were often necessary, due to recurrence ${ }^{(2-3)}$. In patients with significant macular hemorrhages, treatment with photodynamic therapy must be deferred until there is significant clearing of these hemorrhages.

We believe that bevacizumab can be a great choice of treatment for choroidal neovascularization secondary to angioid streaks, related or not to Grönblad-Strandberg syndrome.

\section{RESUMO}

As estrias angióides estão comumente relacionadas à síndrome de Grönblad-Strandberg, que se caracteriza ainda pela presença de alterações dermatológicas caracterizadas pelo pseudoxantoma elástico. A presença de neovascularização coroidiana nesses pacientes é incomum, ocorrendo geralmente após trauma ocular. Relatamos um caso de tratamento bem sucedido de neovascularização coroidiana secundária à síndrome de Grönblad-Strandberg com bevacizumab.

Descritores: Pseudoxantoma elástico; Estrias angióides; Neovascularização coroidal/quimioterapia; Inibidores de angiogênese/uso terapêutico; Relatos de casos [Tipo de publicação] 


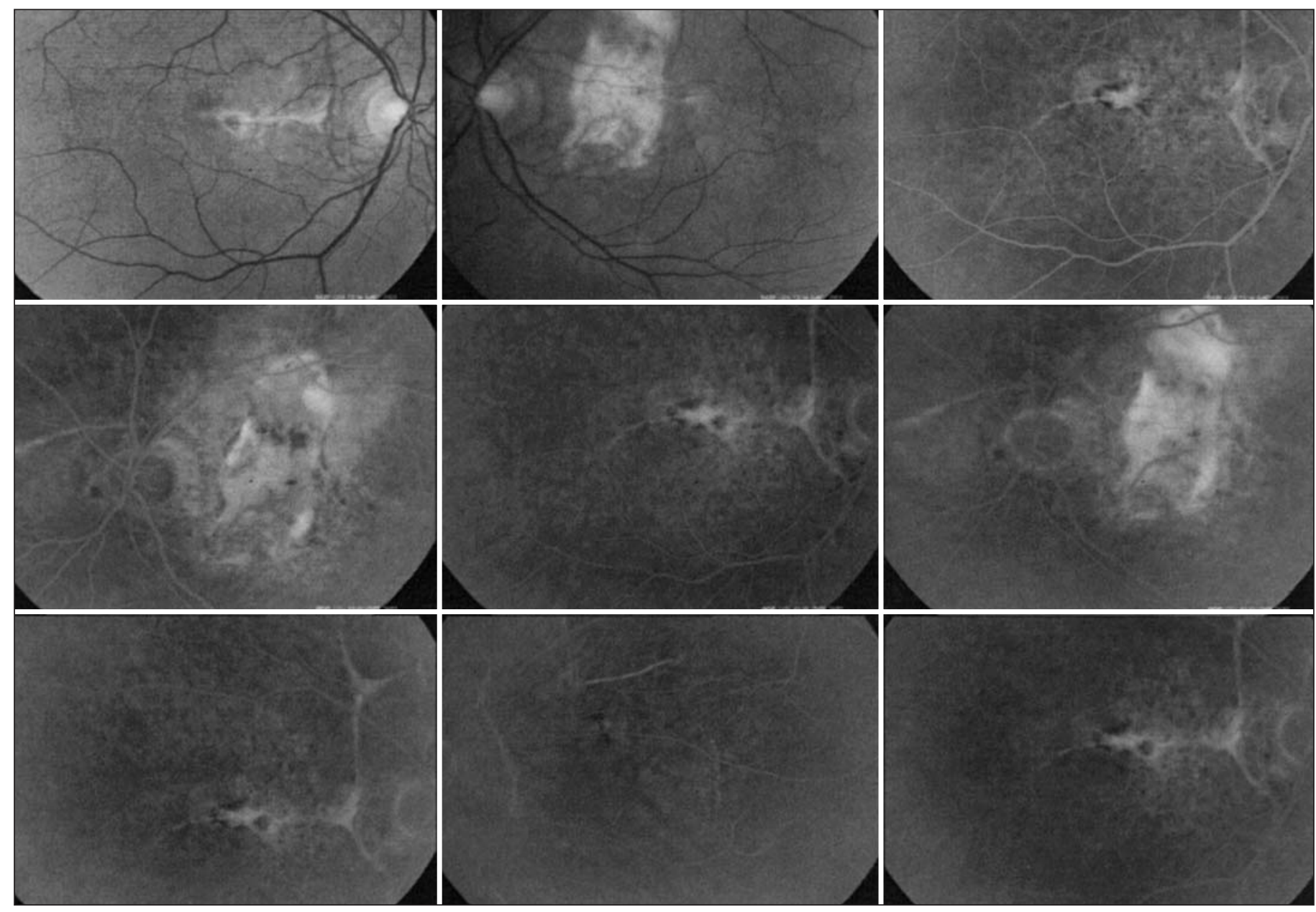

Figure 2 - There was no evidence of macular hemorrhage nor leaking of the neovascular complex in OD one month after bevacizumab

\section{REFERENCES}

1. Rinaldi M, Dell'Omo R, Romano MR, Chiosi F, Cipollone U, Costagliola F. Intravitreal bevacizumab for choroidal neovascularization secondary to angioid streaks. Arch Ophthalmol. 2007;125(10):1422-3.

2. Bhatnagar P, Freund KB, Spaide RF, Klancnik JM Jr, Cooney MJ, Ho I, et al. Intravitreal bevacizumab for the management of choroidal neovascularization in pseudoxanthoma elasticum. Retina. 2007;27(7):897-902.
3. Lommatzsch A, Spital G, Trieschmann M, Pauleikhoff D. [Intraocular application of bevacizumab for the treatment of choroidal neovascularization secondary to angioid streaks]. Ophthalmologe. 2007;104(4):325-8. German.

4. Teixeira A, Moraes N, Farah ME, Bonomo PP. Choroidal neovascularization treated with intravitreal injection of bevacizumab (Avastin) in angioid streaks. Acta Ophthalmol Scand. 2006;84(6):835-6.

5. Pedersen R, Soliman W, Lund-Andersen H, Larsen M. Treatment of choroidal neovascularization using intravitreal bevacizumab. Acta Ophthalmol Scand. 2007;85(5):526-33. 